\title{
The need for social support and the health condition of parents of children with cancer
}

\begin{abstract}
Introduction. Parents of children with cancer are exposed to severe stress which is caused by the process of medical treatment of their child. Mental stress and physical exhaustion are related to the level of support received, provided by different social groups. Health problems are mainly visible in the incidence of somatic symptoms, anxiety and insomnia, functional disorders or symptoms of depression.

Objective. Searching for the relationship between the level of support experienced and the health condition in parents of children with cancer.

Material and methods. The surveyed group consisted of $\mathrm{N}=86$ parents of children with cancer aged from 21 to 53 years $(M=38.70, S D=6.48)$. Women constituted $75.6 \%$ of the respondents, whereas men $24.4 \%$. Social Support Scale by K. Kmiecik-Baran and General Health Questionnaire (GHQ-28) by D. Goldberg were used in the survey.

Results and conclusions. The analyses conducted allowed to detect a link between support and health condition. It transpired that instrumental, valuing and emotional support from family and friends as well as informational and valuing support from professionals are of great importance for well-being.

Palliat Med Pract 2020; 14, 3: 157-165

Key words: social support, health, parents of children with cancer
\end{abstract}

\section{Introduction}

The diagnosis of cancer in a child causes a change in the present life. Child's illness is a critical and stressful situation for the family, especially for parents [1]. Throughout the entire treatment process, parents face many feelings that affect their health, including experiencing symptoms of acute stress disorders, depression and anxiety [2]. In the case of their child's illness, a significant factor for parents is the support they receive not only from their immediate family, friends or acquaintances, but also from medical staff.
Support means assistance available to an individual while experiencing difficult life situations [3]. It appears as a consequence of stressful events in life, such as a personal crisis, illness or life burden [4]. Support is defined as the perception of a person's satisfaction with relations with others and it is related to the overall assessment of quality of life; therefore, it is an important aspect in the functioning of patients and their families [5]. Support is not a homogeneous group of behaviours; it differs in type, degree of severity and source, as well as depends on the needs of the person supported and the supporter's capabilities.

\footnotetext{
Address for correspondence:

Magdalena Katarzyna Pietnoczko

John Paul II Catholic University of Lublin

Al. Racławickie 14, 20-950 Lublin

e-mail: pietnoczko.magdalena@gmail.com

Palliative Medicine in Practice 2020; 14, 3, 157-165

Copyright (C) Via Medica, ISSN 2545-0425

DOI: $10.5603 /$ PMPI.2020.0014
} 
Support giving parents during their child's illness is undoubtedly one of the most expected social behaviours. It is identified with assistance that meets human needs [3]. The most common needs mentioned by parents of sick children include social, informational (usually about their child's health condition) and emotional needs, related to the sense of responsibility and uncertainty [6]. Adequate support reduces the risk of negative impact of disease, both on the sick child and the family, enables parents to function relatively well during the child's illness, allows appropriate organisation of life and care for all family members and the use of their own resources to meet basic psychological and physical needs [7]. A higher level of support, as well as the conviction that it will be available at the right time, results in better adaptation to the cancer situation [8].

Burkiewicz et al. draw attention to the social support that significantly modifies responses to the stress experienced and protects against difficult emotions [9]. A significant factor in the assessment of support is the way it is perceived. It has been shown that the presence of symptoms of depression can be associated with an increased sense of hopelessness, negative thinking and lowered self-esteem. Moreover, the importance of quality of contact with members of medical personnel in coping with the child's illness in parents was confirmed [10].

During contact with nurses, parents can mainly count on instrumental and valuing support, whereas the contact with doctors gives the opportunity to receive instrumental, valuing and informational support. To a lesser extent, nurses and doctors provide emotional support. It has also been found that parents receive significantly lower support from nurses compared to what they expect. The level of support received from doctors and nurses is comparable [11]. A significant role in the demand for social support, which is associated with positive changes in self-perception, has been demonstrated in studies conducted among parents of children with cancer [12].

Cancer is a life-threatening disease and is considered to be a negative life event, especially when it affects one's own child, which is associated with the risk of emotional, cognitive malfunctioning and disturbed parental relationships at different stages of life $[13,14]$. It may also exacerbate the previously occurring mental health disorders and it is related to the health condition of children and parents [15]. Parents may experience significant anxiety during the entire treatment process and draw attention to the need for obtaining appropriate psychosocial interventions, including support, in the course of their child's disease $[16,17]$.
In the context of the above-mentioned considerations, the relationship between the cancer experience of one's own child and the symptoms of depression seems interesting. In the survey by Burkiewicz et al., a significant percentage of parents demonstrated moderate ( $16 \%$ of respondents) or severe $(16 \%)$ intensification of symptoms of depression [9]. The level of depression experienced by parents may not only have a negative impact on their ability to cope with difficulties in everyday life and requirements related to the treatment process, but also on the child's mental state. Carers of cancer patients are burdened with many difficulties that affect their well-being, they experience many symptoms of depression, which are more related to the carers' personality traits and their subjectively assessed burdens, compared to the actual situation of patients and objective burdens [18].

In the presented own surveys, the concept of social support was adopted in Tarde's study, according to which four basic support groups were distinguished: informational, instrumental, valuing and emotional, that can be provided by different social groups [19]. For the purpose of this paper, these were the following groups: family and friends, professionals (doctors, nurses, psychologists). The health condition of the surveyed parents, understood as temporary breakdowns of functioning, was measured in relation to the following dimensions: somatic symptoms, anxiety and insomnia, functioning disorders and depression symptoms [20]. The aim of the survey was to search for and describe the relationships between the level of support experienced and the health condition of parents of children with cancer, as well as to check whether parents with different severity levels of health problems differ in the assessment of support.

\section{Material and methods}

The survey was conducted in a group of 86 ( 65 women, 21 men) parents of children with cancer. The age of the subjects ranged from 21 to 53 years (mean $38.70 \pm 6.48)$. Most surveyed parents $(n=75)$ were married, 6 people described their marital status as single, 4 parents were divorced and 1 person was a widow. Children whose parents were included in the survey were treated for cancer. The most frequent diagnoses in children were leukaemia $(55.8 \%)$ and lymphomata (15.1\%), brain and spinal cord tumours (4.7\%), sympathetic nervous system tumours (e.g. neuroblastoma) (2.3\%), kidney tumours (e.g. Wilms' tumour) (8.1\%), liver tumours (e.g. hepatoblastoma) $(2.3 \%)$ and bone tumours (1.2\%). Sarcomata constituted $4.7 \%$ of the cases; in $3.5 \%$ of children other cancers were diagnosed (i.a. mediastinal tumour). Parents 
Table 1. Diagnostic groups of diseases for which children were treated

\begin{tabular}{lcccccc} 
& \multicolumn{2}{c}{ Girls } & \multicolumn{2}{c}{ Boys } & \multicolumn{3}{c}{ Overall } \\
& $\mathrm{n}$ & $\%$ & $\mathrm{n}$ & $\%$ & $\mathrm{~N}$ & $\%$ \\
\hline Leukaemia & 13 & 41.9 & 35 & 63.6 & 48 & 55.8 \\
\hline Lymphomata & 7 & 22.6 & 6 & 10.9 & 13 & 15.1 \\
\hline Brain and spinal cord tumours & 1 & 3.2 & 3 & 5.5 & 4 & 4.7 \\
\hline $\begin{array}{l}\text { Sympathetic nervous system } \\
\text { tumours }\end{array}$ & 2 & 6.5 & - & - & 2 & 2.3 \\
\hline Kidney tumours & 2 & 6.5 & 5 & 9.1 & 7 & 8.1 \\
\hline Liver tumours & - & - & 2 & 3.6 & 2 & 2.3 \\
\hline Bone tumours & - & - & 1 & 1.8 & 1 & 1.2 \\
\hline Sarcomas & 3 & 9.7 & 1 & 1.8 & 4 & 4.7 \\
\hline Other cancers & 2 & 6.5 & 1 & 1.8 & 3 & 3.5 \\
\hline Undiagnosis & 1 & 3.2 & 1 & 1.8 & 2 & 2.3 \\
\hline Overall & 31 & 100 & 55 & 100 & 86 & 100 \\
\hline
\end{tabular}

of children whose diagnosis was not unequivocally established at the time of the examination, but the clinical picture suggested a diagnosis of cancer and the children were treated symptomatically, were also included in the group of the surveyed persons - this group constituted $2.3 \%$ (Table 1 ).

The surveys were conducted in the period from April 2017 to February 2018, with the agreement of the Research Ethics Committee (REC) and in accordance with the Declaration of Helsinki (DoH). All parents were surveyed individually, after obtaining consent and ensuring the voluntariness, anonymity and confidentiality of the data collected. The subjects were asked to complete the Social Support Scale (SSS) for family and friends, SSS for professionals (doctors, nurses, psychologists) and the Global Health Questionnaire GHQ-28.

The Social Support Scale (SSS) developed by Kmiecik-Baran is designed to measure the severity and type of social support that an individual can receive from different social groups [21]. The questionnaire contains 24 statements consisting of 4 subscales (6 test items each): informational support (e.g. when making important decisions their pieces of advice have proved to be valuable), instrumental support (e.g. it does not usually happen that they come up with a proposal for specific help themselves), valuing support (e.g. when solving important problems my voice is decisive) and emotional (e.g. I feel safe in their company). A person filling in the questionnaire assesses the items according to a 5-stage scale: 1 - this is true; 2 - rather yes; 3 - sometimes yes and sometimes not; 4 - rather not; 5 - not at all. The parents marked their answers in the context of two groups: professionals (doctors, nurses and psychologists) and family and friends. A higher score means a higher support deficit in a given area. The reliability of this method is satisfactory, the $\alpha$-Cronbach coefficient for individual subscale is $0.51-0.87$.

The Global Health Questionnaire GHQ-28 developed by Goldberg and adapted to Polish conditions by Makowska and Merecz [20]. This method is designed to assess the health condition on the basis of a temporary breakdown of functioning. According to the authors, health condition is understood in two ways - as the inability to continue a normal and "healthy" life and as the occurrence of mental distress [22]. The questionnaire contains 28 questions, using a 4-grade scale on which the respondents (by marking the appropriate answer) determined to what extent and with what frequency the problem concerned them. The individual questions are divided into four areas concerning health condition: somatic symptoms (e.g. have you recently had headaches?), anxiety and insomnia (e.g. have you recently had worries that did not let you sleep?), functional disorders (e.g. have you recently been satisfied with the way you perform your tasks?) and symptoms of depression (e.g. have you been thinking about taking your own life recently?). There are several scoring methods for answers, but the Likert's method used in this survey is the most frequently chosen one: 1-2-3-4 [23]. The $\alpha$-Cronbach coefficient of reliability for individual scales is $0.84-0.89$.

\section{Results}

The verification of SSS scores in relation to family and friends, SSS in the context of professionals 
Table 2. Basic scores obtained from the questionnaires applied

\begin{tabular}{|c|c|c|c|c|c|}
\hline \multirow[t]{2}{*}{ Questionnaire } & & \multicolumn{4}{|c|}{$\mathbf{N}=86$} \\
\hline & & Min. & Max. & $\mathbf{M}$ & SD \\
\hline \multirow{5}{*}{$\begin{array}{l}\text { SSS } \\
\text { (family and friends) }\end{array}$} & Informational & 6 & 22 & 12.50 & 3.62 \\
\hline & Instrumental & 6 & 24 & 12.55 & 4.31 \\
\hline & Valuing & 6 & 28 & 12.41 & 4.46 \\
\hline & Emotional & 6 & 21 & 10.62 & 4.29 \\
\hline & Overall score & 24 & 88 & 48.07 & 14.17 \\
\hline \multirow{5}{*}{$\begin{array}{l}\text { SSS } \\
\text { (professionals) }\end{array}$} & Informational & 6 & 23 & 12.34 & 3.24 \\
\hline & Instrumental & 6 & 26 & 16.86 & 3.45 \\
\hline & Valuing & 6 & 27 & 15.23 & 3.67 \\
\hline & Emotional & 6 & 21 & 13.78 & 3.66 \\
\hline & Overall score & 29 & 89 & 58.21 & 10.97 \\
\hline \multirow[t]{5}{*}{ GHQ-28 } & Somatic symptoms & 8 & 28 & 16.10 & 4.72 \\
\hline & Anxiety and insomnia & 9 & 28 & 17.73 & 4.91 \\
\hline & Functional disorders & 9 & 28 & 16.10 & 3.82 \\
\hline & Symptoms of depression & 7 & 23 & 9.56 & 3.47 \\
\hline & Overall score & 36 & 93 & 59.50 & 13.71 \\
\hline
\end{tabular}

(doctors, nurses, psychologists) and GHQ-28 allowed to identify the relationships between these dimensions. The surveys' scores, which constitute psychological characteristics of the surveyed group, are presented in Table 2.

In the context of support from family and friends, the relationship between the symptoms of depression and valuing/emotional support is of great importance. A greater lack of support in these above-mentioned dimensions is accompanied by increased symptoms of depression, while a smaller deficit of instrumental support is associated with a more frequent incidence of functional disorders (Table 3).

GHQ-28 overall score is positively correlated with SSS overall score for doctors, nurses, psychologists. Thus, the greater the deficit of support (especially informational and valuing one) from professionals, the more health problems (most frequently manifesting themselves as symptoms of depression) in the surveyed group of parents. A greater deficit of informational support from professionals is accompanied by a greater number of somatic symptoms; anxiety and insomnia; depression. Low satisfaction of the need for valuing support is correlated with the occurrence of problems related to anxiety and insomnia and symptoms of depression (Table 4).

Cluster analysis conducted using the k-means method allowed the identification of 3 groups of parents, characterised by different severity of health problems (high, low, moderate) (Table 5, Fig. 1). The following interpretations of the scores were adopted for the analysis of the symptom severity graph in particular health dimensions:

- high severity of symptoms - mean above 20;

- moderate severity - 15-20;

- low severity - 10-15;

- very low severity of symptoms - below 10 .

Group $1(n=13)$ is characterised by high scores in such dimensions as somatic symptoms, anxiety and insomnia, functional disorders, whereas low scores - symptoms of depression. Group $2(n=35)$ are parents with low severity level of somatic symptoms, anxiety and insomnia, functional disorders, as well as with very low level of symptoms of depression. Group $3(n=38)$ are persons who show moderate health problems, moderate severity of somatic symptoms, functional disorders; high severity level in terms of anxiety and insomnia, as well as low severity regarding symptoms of depression. The comparisons of individual groups were made by means of the analysis of average scores and standard deviations (Table 6), obtained in individual clusters and using Mann-Whitney $U$ nonparametric test (Table 7).

In groups 1 and 2 (parents with high and low severity of health problems), significant differences were found in each of GHQ-28 dimensions, as well as between groups 2 and 3 (low and moderate severity of health problems). However, when comparing 1 and 3 group of parents (high and moderate severity of health problems), differences occur only in three di- 
Table 3. R-Pearson correlation coefficients between the dimensions of the Social Support Scale regarding family and friends and the General Health Questionnaire GHQ-28

\begin{tabular}{|c|c|c|c|c|c|c|}
\hline \multirow{2}{*}{$\begin{array}{l}\text { Social support } \\
\text { for family } \\
\text { and friends }\end{array}$} & \multirow[b]{2}{*}{ Correlations } & \multicolumn{5}{|c|}{ Health condition } \\
\hline & & $\begin{array}{l}\text { Somatic } \\
\text { symptoms }\end{array}$ & $\begin{array}{c}\text { Anxiety } \\
\text { and insomnia }\end{array}$ & $\begin{array}{l}\text { Functional } \\
\text { disorders }\end{array}$ & Depression & $\begin{array}{l}\text { Overall } \\
\text { score }\end{array}$ \\
\hline \multirow[t]{2}{*}{ Informational } & $r$ & -.012 & -.086 & -.111 & .121 & -.035 \\
\hline & $p$ & .456 & .215 & .154 & .134 & .373 \\
\hline \multirow[t]{2}{*}{ Instrumental } & $r$ & -.097 & -.072 & $-.220^{*}$ & .018 & -.116 \\
\hline & $p$ & .188 & .254 & .021 & .435 & .144 \\
\hline \multirow[t]{2}{*}{ Valuing } & $r$ & -.083 & .001 & .060 & $.222^{*}$ & .045 \\
\hline & $\mathrm{p}$ & .224 & .497 & .293 & .020 & .342 \\
\hline \multirow[t]{2}{*}{ Emotional } & $r$ & -.075 & -.060 & -.102 & $.200 *$ & -.025 \\
\hline & $p$ & .246 & .293 & .174 & .032 & .409 \\
\hline \multirow[t]{2}{*}{ Overall score } & $r$ & -.081 & -.062 & -.108 & .167 & -.038 \\
\hline & $p$ & .228 & .286 & .162 & .062 & .364 \\
\hline
\end{tabular}

${ }^{* *} \mathrm{p}<0.01 ;{ }^{*} \mathrm{p}<0.05$

Table 4. R-Pearson correlation coefficients between the dimensions of the Social Support Scale with regard to professionals (doctors, nurses, psychologists) and the General Health Questionnaire GHQ-28

\begin{tabular}{|c|c|c|c|c|c|c|}
\hline \multirow{2}{*}{$\begin{array}{l}\text { Social support } \\
\text { for professionals }\end{array}$} & \multirow[b]{2}{*}{ Correlations } & \multicolumn{5}{|c|}{ Health condition } \\
\hline & & $\begin{array}{l}\text { Somatic } \\
\text { symptoms }\end{array}$ & $\begin{array}{c}\text { Anxiety } \\
\text { and insomnia }\end{array}$ & $\begin{array}{l}\text { Functional } \\
\text { disorders }\end{array}$ & Depression & $\begin{array}{l}\text { Overall } \\
\text { score }\end{array}$ \\
\hline \multirow[t]{2}{*}{ Informational } & $r$ & $.211 *$ & $.268^{* *}$ & .070 & $.240 *$ & $.249 *$ \\
\hline & $p$ & .026 & .006 & .260 & .013 & .010 \\
\hline \multirow[t]{2}{*}{ Instrumental } & $r$ & .037 & -.102 & -.163 & .119 & -.039 \\
\hline & $p$ & .367 & .176 & .067 & .138 & .361 \\
\hline \multirow[t]{2}{*}{ Valuing } & $r$ & .160 & $.221 *$ & .157 & $.432^{* *}$ & $.287 * *$ \\
\hline & $p$ & .070 & .020 & .074 & .000 & .004 \\
\hline \multirow[t]{2}{*}{ Emotional } & $r$ & .070 & .113 & .023 & .177 & .116 \\
\hline & $p$ & .261 & .150 & .418 & .052 & .144 \\
\hline \multirow[t]{2}{*}{ Overall score } & $r$ & .151 & .159 & .030 & $.311 * *$ & $.196^{*}$ \\
\hline & $\mathrm{p}$ & .083 & .072 & .393 & .002 & .035 \\
\hline
\end{tabular}

${ }^{* *} \mathrm{p}<0.01 ;{ }^{*} \mathrm{p}<0.05$

mensions: somatic symptoms, anxiety and insomnia, functional disorders.

The groups selected differ from professionals (doctors, nurses, psychologists) in their experience of valuing support, which was shown in the analysis using the Kruskal-Wallis test. Detailed statistics are presented in Tables 8 and 9. The scores required multiple comparisons, from which it was found that the valuing support from professionals differentiates groups 2 and 3 - parents with moderate severity of health problems have a greater need for such support, compared to parents with low severity of health problems. Significant differences between groups in terms of support from professionals are shown in Table 10.

\section{Discussion}

The scores of the conducted survey confirm the scores obtained in surveys by other authors. The link between the support experienced and the health condition of parents struggling with their child's illness is particularly evident with regard to the group of professionals. Persons who assessed the support from doctors, nurses and psychologists as satisfactory are characterised by better well-being. The surveys of parents of hospitalised children have shown that the informational, emotional, valuing and instrumental support of nurses and doctors is comparable. The respondents also indicate that the support they receive 
Table 5. Number of persons surveyed in clusters

\begin{tabular}{|c|c|c|}
\hline Number of persons in particular clus & rs ( & 86) \\
\hline Cluster & $\mathbf{n}$ & $\%$ \\
\hline $\begin{array}{l}\text { Group } 1-\text { parents with high severi- } \\
\text { ty of health problems }\end{array}$ & 13 & 15.1 \\
\hline $\begin{array}{l}\text { Group } 2 \text { - parents with low severity } \\
\text { of health problems }\end{array}$ & 35 & 40.7 \\
\hline $\begin{array}{l}\text { Group } 3 \text { - parents with moderate } \\
\text { severity of health problems }\end{array}$ & 38 & 44.2 \\
\hline
\end{tabular}

is much lower than expected, especially in the area of instrumental support [11]. In addition, according to other surveys, people whose various expectations towards others are not met, can feel many difficult emotions. One can deduce that the unmet needs (i.a. support) are reflected in the expression of dissatisfaction with care [24].

Among the variables determining patient satisfaction with the quality of medical care are i.a. the need for information, interest and social support [25, 26]. Analyses conducted on the basis of own research confirm that a greater deficit of informational support from professionals is associated with somatic ailments, feeling of anxiety and insomnia as well as symptoms of depression. However, this problem seems to be more complex because, as surveys by Maree et al. [27] have found, individual parents have different opinions about how, when and exactly what information should be provided to them. The authors emphasise

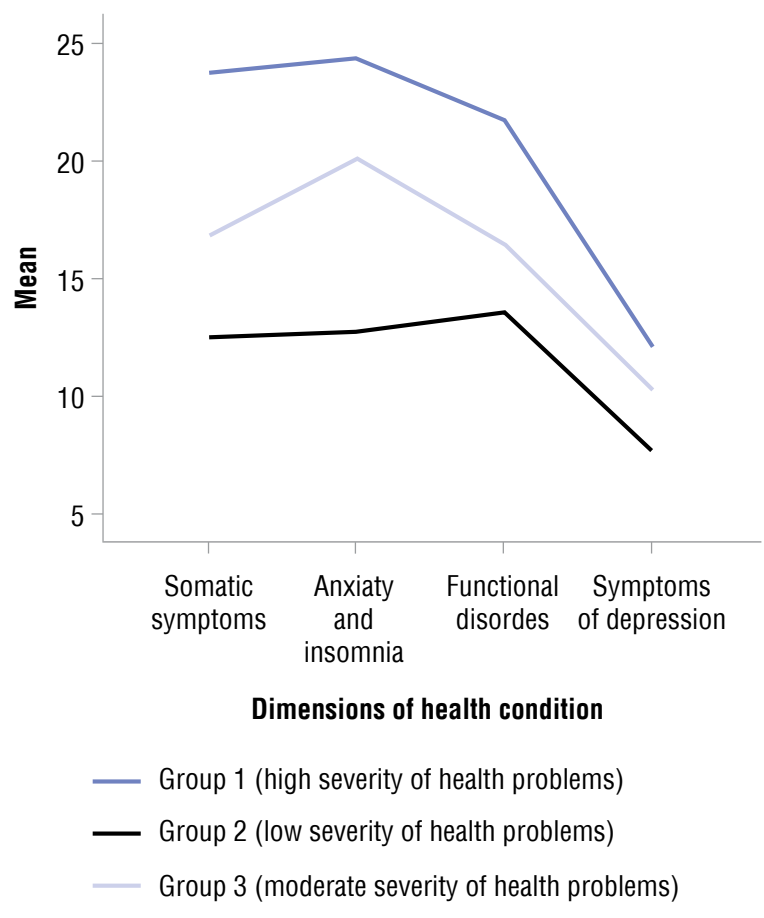

Figure 1. Clusters in terms of the dimensions of health condition

the importance of an individualised approach to providing information on the child's health, affecting the parents' quality of life. In our own research, the general level of support from professionals is related to the health condition in the surveyed group - the greater its deficit, the worse the well-being of parents.

Table 6. Average scores and standard deviations in groups for individual health dimensions

\begin{tabular}{lccccccc}
$\begin{array}{l}\text { Dimensions of health } \\
\text { condition }\end{array}$ & \multicolumn{2}{c}{ Group $1(\mathrm{n}=13)$} & \multicolumn{2}{c}{ Group $2(\mathrm{n}=35)$} & \multicolumn{2}{c}{ Group $3(\mathrm{n}=38)$} \\
Somatic symptoms & $\mathrm{M}$ & $\mathrm{SD}$ & $\mathrm{M}$ & $\mathrm{SD}$ & $\mathrm{M}$ & $\mathrm{SD}$ \\
\hline Anxiety and insomnia & 23.77 & 3.37 & 12.49 & 2.20 & 16.82 & 3.08 \\
\hline Functional disorders & 24.38 & 2.75 & 12.74 & 1.88 & 20.05 & 2.27 \\
\hline Symptoms of depression & 21.77 & 4.23 & 13.60 & 1.44 & 16.47 & 2.90 \\
\hline
\end{tabular}

Table 7. Relevance of differences among groups for various dimensions of health

\begin{tabular}{|c|c|c|c|c|c|c|}
\hline \multirow[t]{2}{*}{$\begin{array}{l}\text { Dimensions of health } \\
\text { condition }\end{array}$} & \multicolumn{2}{|c|}{$\begin{array}{l}\text { Comparison of groups } \\
1 \text { and } 2\end{array}$} & \multicolumn{2}{|c|}{$\begin{array}{l}\text { Comparison of groups } \\
1 \text { and } 3\end{array}$} & \multicolumn{2}{|c|}{$\begin{array}{l}\text { Comparison of groups } \\
2 \text { and } 3\end{array}$} \\
\hline & $\begin{array}{c}\text { Mann-Whitney } \\
\text { U test }\end{array}$ & $\mathbf{p}$ & $\begin{array}{c}\text { Mann-Whitney } \\
\text { U test }\end{array}$ & $\mathbf{p}$ & $\begin{array}{c}\text { Mann-Whitney } \\
\text { U test }\end{array}$ & $\mathbf{p}$ \\
\hline Somatic symptoms & $-5.288^{*}$ & .000 & $-4 ., 547^{*}$ & .000 & $-5.803^{*}$ & .000 \\
\hline Anxiety and insomnia & $-5.331 *$ & .000 & $-4.162^{*}$ & .000 & $-7.307^{*}$ & .000 \\
\hline Functional disorders & $-5.119 *$ & .000 & $-3.758^{*}$ & .000 & $-4.927^{*}$ & .000 \\
\hline Symptoms of depression & $-4.086^{*}$ & .000 & -1.471 & .141 & $-4.400 *$ & .000 \\
\hline
\end{tabular}


Table 8. Average scores and standard deviations in groups for individual dimensions of social support

\begin{tabular}{|c|c|c|c|c|c|c|}
\hline & \multicolumn{2}{|c|}{ Group $1(n=13)$} & \multicolumn{2}{|c|}{ Group $2(n=35)$} & \multicolumn{2}{|c|}{ Group $3(n=38)$} \\
\hline & M & SD & $\mathbf{M}$ & SD & $\mathbf{M}$ & SD \\
\hline \multicolumn{7}{|c|}{ Social support from family and friends } \\
\hline Informational & 11.69 & 3.57 & 12.80 & 3.75 & 12.50 & 3.58 \\
\hline Instrumental & 11.08 & 3.38 & 12.74 & 4.55 & 12.87 & 4.36 \\
\hline Valuing & 11.62 & 4.33 & 12.29 & 4.99 & 12.79 & 4.05 \\
\hline Emotional & 9.15 & 3.31 & 10.83 & 4.67 & 10.92 & 4.23 \\
\hline Overall score & 43.54 & 11.47 & 48.66 & 15.44 & 49.08 & 13.82 \\
\hline \multicolumn{7}{|c|}{ Social support from professionals } \\
\hline Informational & 12.77 & 5.15 & 11.34 & 3.00 & 13.11 & 2.38 \\
\hline Instrumental & 16.00 & 5.49 & 16.80 & 2.76 & 17.21 & 3.18 \\
\hline Valuing & 14.62 & 4.66 & 13.97 & 3.05 & 16.61 & 3.43 \\
\hline Emotional & 13.23 & 4.66 & 13.34 & 3.54 & 14.37 & 3.40 \\
\hline Overall score & 56.62 & 17.12 & 55.46 & 9.36 & 61.29 & 9.13 \\
\hline
\end{tabular}

Table 9. Differences between groups in terms of social support

\begin{tabular}{lcc}
\multicolumn{4}{c}{$\mathrm{x}^{2}$} & $\mathrm{P}$ \\
\multicolumn{4}{l}{ Social support from family and friends } \\
\hline Informational & .746 & .689 \\
\hline Instrumental & 1.415 & .493 \\
\hline Valuing & 1.289 & .525 \\
\hline Emotional & 1.937 & .380 \\
\hline Overall score & 1.158 & .560 \\
\hline Social support from professionals & \\
\hline Informational & 5.014 & .082 \\
\hline Instrumental & .589 & .745 \\
\hline Valuing & $8.200^{*}$ & .017 \\
\hline Emotional & 1.331 & .514 \\
\hline Overall score & 5.482 & .065 \\
\hline
\end{tabular}

It should be mentioned that the valuing support assessed in relation to a group of professionals differentiates the group with low and moderate severity of health problems. Parents in group 2 (low severity of health problems) have a lower need for valuing support, compared to group 3 (moderate severity). In other words, less need to ensure others that you are an important person to be reckoned with is associated with better well-being. In the context of this observation, the question can be formulated as to why these differences were not found in comparison with the group with high health problems. Perhaps the group of parents with the greatest health problems was less numerous or their own health problems cause the issue of support to be irrelevant to them. However, these hypotheses should be investigated in future research.

The most significant support group during the child's illness is the family [26]. Our own research has shown that parents who believe that they are important to their loved ones have fewer symptoms of depression. Cognitively interesting is the survey result, according to which greater satisfaction of parents regarding instrumental support received from family and friends is correlated with more frequently experienced difficulties in functioning. Perhaps the constant offering of help by the loved ones makes the respondents feel as if they are unable to function normally in the opinion of others. However, the survey should be expanded to reach a clear conclusion.

The surveys conducted so far confirm the need to develop and apply social support programmes for parents of children with cancer $[9,28,29]$. The results presented and the conclusions drawn from them may be applicable in clinical practice. Perhaps some of the health problems of parents of children with cancer are due to dissatisfaction with the social support experienced and its inadequacy. An appropriate support network and a response to parents' expectations can help them cope with their child's illness. However, it should be remembered that the studies conducted have certain limitations. The variables that have been submitted to verification do not fully explain the problems of parents of children with cancer. Each person is different and only individual, yet holistic approach to a person, can be useful in understanding them and helping in the spheres of life to which the other person is invited. 
Table 10. The importance of differences between groups for social support from professionals

\begin{tabular}{lcccccc}
$\begin{array}{l}\text { Social support fro } \\
\text { professionals }\end{array}$ & $\begin{array}{c}\text { Comparison of groups } \\
1 \text { and } 2\end{array}$ & $\begin{array}{c}\text { Mann-Whitney } \\
\text { U test }\end{array}$ & $p$ & $\begin{array}{c}\text { Mann-Whitney } \\
\text { U test }\end{array}$ & $p$ & $\begin{array}{c}\text { Mann-Whitney } \\
\text { U test }\end{array}$ \\
Informational & -.896 & .370 & -.196 & .845 & $-2.334^{*}$ & .020 \\
\hline Instrumental & -.573 & .567 & -.708 & .479 & -.361 & .718 \\
\hline Valuing & -.665 & .506 & -.946 & .344 & $-2.972^{*}$ & .003 \\
\hline Emotional & -.093 & .926 & -.728 & .467 & -1.093 & .274 \\
\hline Overall score & -.209 & .834 & -.919 & .358 & $-2.438^{*}$ & .015 \\
\hline
\end{tabular}

\section{Conclusions}

In the group of parents of children with cancer, lack of informational support received from professionals is accompanied by somatic ailments, feeling of anxiety and insomnia as well as symptoms of depression.

Less need for the valuing support from professionals is associated with better well-being of parents.

Parents who are satisfied with the support they receive from the loved ones experience fewer symptoms of depression.

\section{Conflict of interests}

The authors declare no conflict of interest.

\section{Funding}

This study has no funding.

\section{References}

1. Zuberek-Moskal U. Rodzina w sytuacji wyznaczonej chorobą nowotworową dziecka. In: Kubacka-Jasiecka D, Łosiak W. ed. Zmagając Się z Chorobą Nowotworową. Psychologia Wobec Pacjentów Onkologicznych. Wydawnictwo Uniwersytetu Jagiellońskiego, Kraków 1999: 261-263.

2. Muscara F, McCarthy MC, Woolf C, et al. Early psychological reactions in parents of children with a life threatening illness within a pediatric hospital setting. Eur Psychiatry. 2015; 30(5): 555-561, doi: 10.1016/j.eurpsy.2014.12.008, indexed in Pubmed: 25618445.

3. Deręgowska J. Dziecko z Chorobą Nowotworową w Rodzinie. Diagnoza-Wsparcie. Wydawnictwo Naukowe Wyższej Szkoły Nauk Humanistycznych i Dziennikarstwa, Poznań 2010.

4. Sęk H, Cieślak R. Wsparcie społeczne - sposoby definiowania, rodzaje i źródła wsparcia, wybrane koncepcje teoretyczne. In: Sęk H, Cieślak R. ed. Wsparcie społeczne, stres i zdrowie. Wydawnictwo Naukowe PWN, Poznań 2006: 11-28.

5. Kacperczyk A. Wsparcie Społeczne w Instytucjach Opieki Paliatywnej i Hospicyjnej. Wydawnictwo Uniwersytetu Łódzkiego, Łódź 2006.

6. Pelentsov L, Laws TA, Esterman AJ. The supportive care needs of parents caring for a child with a rare disease: A scoping review. Disabil Health J. 2015; 8(4): 475-491, doi: 10.1016/j.dhjo.2015.03.009, indexed in Pubmed: 25959710.
7. Ziółkowska B. Dziecko chore w domu, w szkole i u lekarza. Jak wspomagać rozwój dzieci przewlekle chorych. Gdańskie Wydawnictwo Psychologiczne, Gdańsk 2010.

8. Wyszomirska J, Gajda M, Janas J, et al. Ocena wpływu wsparcia społecznego na psychiczne przystosowanie do choroby nowotworowej pacjentów w trakcie leczenia paliatywnego lub radykalnego. Psychoonkologia. 2014; 3: 89-96.

9. Burkiewicz A, Samardakiewicz M, Karczmarczyk T. The level of depression and perceived social support in parents of children treated for cancer. Psychoonkologia. 2017; 21(1): 17-21, doi: 10.5114/pson.2017.70123.

10. Kędzierska B, Rol P, Wiktorowicz J. Indicators of posttraumatic stress in parents of children finishing cancer treatment - the role of medical care, social support and resiliency. Psychoonkologia. 2016; 20(1): 9-16, doi: 10.5114/pson.2016.60922.

11. Mazur A, Aftyka A, Sipta A, et al. Expected and received support from the medical personnel in the perception of parents of children treated in hospital. Psychoonkologia. 2016; 20(4): 183-190, doi: 10.5114/pson.2016.66290.

12. Ogińska-Bulik N. Personal resources and posttraumatic growth of parents struggling with cancer disease of their child. Psychoonkologia. 2017; 21(1): 9-16, doi: 10.5114/pson.2017.70122.

13. Ogińska-Bulik N, Socha I. Emotional processing and negative and positive effects of trauma among parents struggling with cancer of their child. Psychoonkologia. 2017; 21(1): 1-8, doi: 10.5114/pson.2017.70121.

14. Kazak AE, Boeving CA, Alderfer MA, et al. Posttraumatic stress symptoms during treatment in parents of children with cancer. J Clin Oncol. 2005; 23(30): 7405-7410, doi: 10.1200/JCO.2005.09.110, indexed in Pubmed: 16157936.

15. Hamner T, Latzman RD, Latzman NE, et al. Quality of life among pediatric patients with cancer: Contributions of time since diagnosis and parental chronic stress. Pediatr Blood Cancer. 2015; 62(7): 1232-1236, doi: 10.1002/pbc.25468, indexed in Pubmed: 25755193.

16. Pöder U, Ljungman G, von Essen L. Posttraumatic stress disorder among parents of children on cancer treatment: a longitudinal study. Psychooncology. 2008; 17(5): 430-437, doi: 10.1002/pon.1263, indexed in Pubmed: 17847123.

17. Sloper P. Predictors of distress in parents of children with cancer: a prospective study. J Pediatr Psychol. 2000; 25(2): 79-91, doi: 10.1093/jpepsy/25.2.79, indexed in Pubmed: 10820946.

18. Yang X, Wang L, He J, et al. Factors related to depressive symptoms among Chinese caregivers of cancer patients. Psycho-Oncology. 2011; 21(10): 1063-1070, doi: 10.1002/pon.1999. 
19. Tardy C. Social suport measurment. American Journal of Community Psychology. 1985; 13(2): 187-202.

20. Makowska Z, Merecz D. Polska adaptacja kwestionariuszy ogólnego stanu zdrowia Davida Goldberga GHQ12 i GHQ-28. In: Dudek B. ed. Ocena zdrowia psychicznego na podstawie badań kwestionariuszami Davida Goldberga. Instytut Medycyny Pracy im. prof. J. Nofera, Łódź 2001: 191-264.

21. Kmiecik-Baran K. Skala Wsparcia Społecznego. Teoria i wartości psychometryczne. Przegląd Psychologiczny. 1995; 38(1/2): 201-214

22. Goldberg D, Williams P. Podręcznik dla użytkowników Kwestionariusza Ogólnego Stanu Zdrowia (translation: D. Merecz). In: Dudek B. ed. Ocena zdrowia psychicznego na podstawie badań kwestionariuszami Davida Goldberga. Instytut Medycyny Pracy im. prof. J. Nofera, Łódź 2001: 13-189.

23. Frydecka D, Małyszczak K, Chachaj A, et al. Struktura czynnikowa Kwestionariusza Ogólnego Zdrowia (GHQ-30). Psychiatria Polska 2010; XLIV. ; 3: 341-359.
24. Moczydłowska A, Krajewska-Kułak E, Kózka M, et al. Oczekiwania chorych wobec personelu lekarskiego. Hygeia Public Health. 2014; 49(1): 142-151.

25. Mykowska A. Satysfakcja pacjenta a jakość obsługi medycznej. Zdrowie i Zarządzanie. 2002; 6: 69-73.

26. Grzegorczyk A, Szewczyk L. Ocena wsparcia społecznego rodziców dzieci z chorobami neurologicznymi. Aspekty zdrowia i Chor. 2016; 1(4): 55-65.

27. Maree JE, Parker S, Kaplan L, et al. The Information Needs of South African Parents of Children With Cancer. J Pediatr Oncol Nurs. 2016; 33(1): 9-17, doi: 10.1177/1043454214563757, indexed in Pubmed: 25643969.

28. Kamihara J, Nyborn JA, Olcese ME, et al. Parental hope for children with advanced cancer. Pediatrics. 2015; 135(5): 868-874, doi: 10.1542/peds.2014-2855, indexed in Pubmed: 25847801.

29. Masa'deh R, Jarrah S. Post Traumatic Stress Disorder in Parents of Children With Cancer in Jordan. Arch Psychiatr Nurs. 2017; 31(1): 8-12, doi: 10.1016/j.apnu.2016.07.012, indexed in Pubmed: 28104064. 


\section{Potrzeba wsparcia społecznego a stan zdrowia rodziców dzieci chorych na nowotwory}

Artykuł jest tłumaczeniem pracy: Pietnoczko M., Steuden S., The need for social support and the health condition of parents of children with cancer. Palliat. Med. Pract. 2020 tom 14, nr 3: 157-165.

Należy cytować wersję pierwotną.

\section{Streszczenie}

Wstęp. Rodzice dzieci z chorobami nowotworowymi narażeni są na przeżywanie silnego stresu, który spowodowany jest procesem leczenia dziecka. Psychiczne obciążenie i fizyczne wyczerpanie ma związek z poziomem doświadczanego wsparcia, które udzielane jest przez różne grupy społeczne. Trudności w zakresie zdrowia widoczne są przede wszystkim w występowaniu objawów somatycznych, niepokoju i bezsenności, zaburzeniach funkcjonowania czy symptomach depresji.

Cel pracy. Poszukiwanie związku między poziomem doświadczanego wsparcia a stanem zdrowia u rodziców dzieci z chorobami nowotworowymi.

Materiał i metody. Grupę badaną stanowiło $\mathrm{n}=86$ rodziców dzieci z chorobami nowotworowymi w wieku 21-53 lat $(M=38,70, S D=6,48)$. Kobiety stanowiły 75,6\% badanych, a mężczyźni $24,4 \%$. W badaniach wykorzystano Skalę Wsparcia Społecznego K. Kmiecik-Baran oraz Kwestionariusz Ogólnego Stanu Zdrowia GHQ-28 D. Goldberga.

Wyniki i wnioski. Przeprowadzone analizy pozwoliły na wykrycie związku między wsparciem a stanem zdrowia. Okazało się, że znaczenie dla samopoczucia ma wsparcie instrumentalne, wartościujące i emocjonalne od rodziny i przyjaciół oraz wsparcie informacyjne i wartościujące od profesjonalistów.

Palliat Med Pract 2020; 14, 3: 166-174

Słowa kluczowe: wsparcie społeczne, zdrowie, rodzice dzieci z chorobami nowotworowymi

\section{Wstęp}

Rozpoznanie choroby nowotworowej u dziecka powoduje zmianę dotychczasowego życia. Choroba dziecka jest sytuacją krytyczną i stresującą dla rodziny, a zwłaszcza dla rodziców [1]. Podczas całego procesu leczenia rodzice borykają się z wieloma uczuciami, które wpływają na stan ich zdrowia, w tym na do- świadczanie objawów ostrych zaburzeń stresowych, depresji i niepokoju [2]. W sytuacji choroby dziecka dla rodziców istotnym czynnikiem jest wsparcie, jakie uzyskują nie tylko od najbliższej rodziny, przyjaciół czy znajomych, ale także od personelu medycznego.

Wsparcie oznacza pomoc, która dostępna jest jednostce podczas przeżywania trudnych sytuacji życiowych [3]. Pojawia się, jako konsekwencja na stresujące

\section{Adres do korespondencji:}

Magdalena Katarzyna Pietnoczko

Katolicki Uniwersytet Lubelski Jana Pawła II

Al. Racławickie 14, 20-950 Lublin

e-mail: pietnoczko.magdalena@gmail.com 
wydarzenia w życiu, takie jak osobisty kryzys, choroba lub życiowe obciążenia [4]. Wsparcie definiowane jest jako percepcja zadowolenia osoby z relacji z innymi i ma związek z ogólną oceną jakości życia, dlatego jest ważnym aspektem w problematyce funkcjonowania osób chorych i ich rodzin [5]. Wsparcie nie stanowi jednolitej grupy zachowań, różni się rodzajem, stopniem nasilenia, źródłem, pozostaje także zależne od potrzeb osoby wspieranej i możliwości osoby wspierającej.

Wsparcie rodziców w sytuacji choroby dziecka jest niewątpliwie jednym z najbardziej oczekiwanych zachowań społecznych. Utożsamiane jest z pomocą, która odpowiada potrzebom ludzkim [3]. Najczęstsze potrzeby wymieniane przez rodziców dzieci chorych to potrzeby społeczne, informacyjne (najczęściej o stanie zdrowia dziecka) i emocjonalne, związane z poczuciem odpowiedzialności i niepewnością [6]. Adekwatne wsparcie zmniejsza ryzyko negatywnego oddziaływania choroby, zarówno na dziecko chore, jak i na rodzinę, umożliwia rodzicom względnie dobre funkcjonowanie w sytuacji choroby dziecka, pozwala na odpowiednią organizację życia i opieki wszystkim członkom rodziny i na wykorzystanie własnych zasobów celem zaspokojenia podstawowych potrzeb psychicznych i fizycznych [7]. Wyższy poziom wsparcia, a także przekonanie, że będzie dostępne w odpowiedniej chwili, skutkuje lepszym przystosowaniem do sytuacji choroby nowotworowej [8].

Burkiewicz i wsp. zwracają uwagę na wsparcie społeczne, które znacząco modyfikuje reakcje na odczuwany stres i chroni przed trudnymi emocjami [9]. Czynnikiem znaczącym w ocenie wsparcia jest sposób jego spostrzegania. Wykazano, że obecność objawów depresyjnych może być związana ze zwiększonym poczuciem beznadziejności, myśleniem negatywnym i obniżoną samooceną. Potwierdzono również istotę jakości kontaktu z członkami personelu medycznego w radzeniu sobie z chorobą dziecka u rodziców [10].

W kontakcie z pielęgniarkami rodzice mogą liczyć głównie na wsparcie instrumentalne i wartościujące, zaś kontakt z lekarzami daje możliwość otrzymania wsparcia instrumentalnego, wartościującego $\mathrm{i}$ informacyjnego. W mniejszym stopniu pielęgniarki i lekarze udzielają wsparcia emocjonalnego. Wykazano również, że rodzice otrzymują od pielęgniarek istotnie niższe wsparcie w porównaniu z tym, jakiego oczekują. Poziom wsparcia otrzymywanego od lekarzy i pielęgniarek jest porównywalny [11]. Istotne znaczenie w zapotrzebowaniu na wsparcie społeczne, które wiąże się z pozytywnymi zmianami w zakresie percepcji siebie, wykazano w badaniach przeprowadzonych wśród rodziców dzieci chorych na nowotwory [12].

Choroba nowotworowa zagraża życiu i jest zaliczana do negatywnych wydarzeń życiowych, zwłaszcza kiedy dotyczy własnego dziecka, co wiąże się z ryzykiem zaburzenia funkcjonowania emocjonalnego, poznawczego i relacji rodziców na różnych etapach życia $[13,14]$. Może także nasilić występujące wcześniej zaburzenia zdrowia psychicznego i pozostaje w związku ze stanem zdrowia dzieci i ich samych [15]. Rodzice podczas całego procesu leczenia moga doświadczać znacznego niepokoju i zwracają uwagę na potrzebę uzyskiwania odpowiednich interwencji psychospołecznych w przebiegu choroby dziecka, w tym wsparcia $[16,17]$.

Interesujący w kontekście powyższych rozważań wydaje się związek doświadczenia choroby nowotworowej własnego dziecka z objawami depresji. W badaniu Burkiewicz i wsp. znaczny odsetek rodziców wykazywał umiarkowane (16\% badanych) bądź ciężkie (16\%) nasilenie objawów depresji [9]. Poziom przeżywanej depresji rodziców może nie tylko wpływać negatywnie na umiejętność radzenia sobie z trudnościami w codziennym funkcjonowaniu i z wymaganiami związanymi z procesem leczenia, ale także na stan psychiczny dziecka. Opiekunowie chorych na nowotwory są obciążeni wieloma trudnościami, które wpływają na samopoczucie, doświadczają wielu objawów depresji, które wykazują większy związek $z$ cechami opiekunów $\mathrm{i}$ ich subiektywnie ocenianymi obciążeniami, w porównaniu z faktyczną sytuacją pacjentów i obiektywnymi obciążeniami [18].

W przedstawianych badaniach własnych przyjęto koncepcję wsparcia społecznego w opracowaniu Tardy'ego, według którego wyróżniono cztery podstawowe grupy wsparcia: informacyjne, instrumentalne, wartościujące i emocjonalne, które może być udzielane przez różne grupy społeczne [19]. Dla potrzeb niniejszej pracy były to następujące grupy: rodzina i przyjaciele oraz profesjonaliści (lekarze, pielęgniarki, psychologowie). Stan zdrowia badanych rodziców, rozumiany jako chwilowe załamania funkcjonowania, mierzono w odniesieniu do wymiarów: objawy somatyczne, niepokój i bezsenność, zaburzenia funkcjonowania i objawy depresji [20]. Celem badania było poszukiwanie i opisanie związków między poziomem doświadczanego wsparcia a stanem zdrowia rodziców dzieci z chorobami nowotworowymi, a także sprawdzenie, czy rodzice o różnym nasileniu problemów zdrowotnych, różnią się między sobą w ocenie wsparcia.

\section{Materiał i metody}

Badanie przeprowadzone w grupie 86 (65 kobiet, 21 mężczyzn) rodziców dzieci z chorobami nowotworowymi. Wiek badanych zawierał się $w$ przedziale 21-53 lata (średnia 38,70 $\pm 6,48$ ). Najwięcej badanych 
Tabela 1. Grupy diagnostyczne chorób, z powodu których leczone były dzieci rodziców objętych badaniami

\begin{tabular}{lcccccc} 
Grupa diagnostyczna & \multicolumn{2}{c}{ Dziewczynki } & \multicolumn{2}{c}{ Chłopcy } & \multicolumn{2}{c}{ Ogółem } \\
& $n$ & $\%$ & $n$ & $\%$ & $n$ & 55,8 \\
\hline Białaczki & 13 & 41,9 & 35 & 63,6 & 48 & 13,1 \\
\hline Chłoniaki & 7 & 22,6 & 6 & 10,9 & 13 & 4,7 \\
\hline Mózg i rdzeń kręgowy & 1 & 3,2 & 3 & 5,5 & 4 & 2,3 \\
\hline Układ nerwowy współczulny & 2 & 6,5 & - & - & 2 & 8,1 \\
\hline Nerki & 2 & 6,5 & 5 & 9,1 & 7 & 2,3 \\
\hline Wątroba & - & - & 2 & 3,6 & 2 & 1,2 \\
\hline Kości & - & - & 1 & 1,8 & 1 & 4,7 \\
\hline Mięsaki & 3 & 9,7 & 1 & 1,8 & 4 & 3,5 \\
\hline Inne & 2 & 6,5 & 1 & 1,8 & 3 & 2,3 \\
\hline Brak diagnozy & 1 & 3,2 & 1 & 1,8 & 2 & 100 \\
\hline Ogółem & 31 & 100 & 55 & 100 & 86 & \\
\hline
\end{tabular}

rodziców ( $\mathrm{n}=75)$ pozostawało w związku małżeńskim, 6 osób stan cywilny określiło jako wolny/wolna, 4 rodziców było po rozwodzie, a 1 osoba była wdową. Dzieci, których rodzice zostali włączeni do badań, były poddawane leczeniu z powodu choroby nowotworowej. Najczęstszym rozpoznaniem u dzieci były białaczki $(55,8 \%)$ i chłoniaki $(15,1 \%)$, nowotwory mózgu i rdzenia kręgowego (4,7\%), guzy układu nerwowego współczulnego (np. neuroblastoma) (2,3\%), nerek (np. guz Wilmsa) $(8,1 \%)$, wątroby (np. hepatoblastoma) (2,3\%) i nowotwory kości (1,2\%). Mięsaki stanowiły $4,7 \%$ zachorowań, a u 3,5\% dzieci rozpoznano inne nowotwory (m.in. guz śródpiersia). Do grupy osób badanych włączono również rodziców dzieci, u których w czasie przeprowadzania badania nie ustalono jednoznacznie rozpoznania, ale obraz kliniczny sugerował rozpoznanie choroby nowotworowej i dzieci były leczone objawowo - grupa ta stanowiła 2,3\% (tab. 1).

Badania przeprowadzono w okresie od kwietnia 2017 do lutego 2018 roku za zgodą Komisji Etyki Badań Naukowych i zgodnie z Deklaracją Helsińską. Wszystkich rodziców badano indywidualnie, po uzyskaniu zgody i zapewnieniu dobrowolności, anonimowości i poufności zebranych danych. Osoby badane poproszono o wypełnienie Skali Wsparcia Społecznego w odniesieniu do rodziny i przyjaciół, Skali Wsparcia Społecznego w odniesieniu do profesjonalistów (lekarzy, pielęgniarek, psychologów) i Kwestionariusza Ogólnego Stanu Zdrowia (GHQ-28, Global Health Questionnaire).

Skala Wsparcia Społecznego (SWS) opracowana przez Kmiecik-Baran jest przeznaczona do pomiaru siły i rodzaju wsparcia społecznego, które jednostka może otrzymać od różnych grup społecznych [21].
Kwestionariusz zawiera 24 stwierdzenia składające się na 4 podskale (po 6 pozycji testowych w każdej): wsparcie informacyjne, na przykład przy podejmowaniu ważnych decyzji ich rady okazały się cenne; instrumentalne, na przykład na ogół nie zdarza się, by sami od siebie wyszli z propozycją konkretnej pomocy; wartościujące, na przykład przy rozstrzyganiu ważnych problemów mój głos jest decydujący; i emocjonalne, $\mathrm{np}$. w ich towarzystwie czuję się bezpieczny. Osoba wypełniająca kwestionariusz ocenia pozycje według 5-stopniowej skali: 1 - jest właśnie tak, 2 - raczej tak, 3 - czasem tak jest, a czasem nie, 4 - raczej tak nie jest, 5 - zupełnie tak nie jest. Badani rodzice zaznaczali odpowiedzi w kontekście dwóch grup: profesjonalistów (lekarzy, pielęgniarek i psychologów) oraz rodziny i znajomych. Wyższy wynik oznacza większy deficyt wsparcia w danym obszarze. Rzetelność metody jest zadowalająca, współczynnik $\alpha$-Cronbacha dla poszczególnych podskal wynosi 0,51-0,87.

Kwestionariusz Ogólnego Stanu Zdrowia opracowany przez Goldberga w adaptacji do warunków polskich Makowskiej i Merecz [20]. Metoda przeznaczona jest do oceny stanu zdrowia na podstawie chwilowego załamania funkcjonowania. Według autorów stan zdrowia rozumiany jest w dwojaki sposób — jako niezdolność do kontynuacji normalnego i „zdrowego” życia, a także jako występowanie psychicznego dystresu [22]. Kwestionariusz składa się z 28 pytań, w skali 4-stopniowej, na której badani poprzez zaznaczenie odpowiedniej odpowiedzi określali, w jakim stopniu i z jaką częstością dany problem ich dotyczy. Poszczególne pytania podzielono na cztery obszary dotyczące stanu zdrowia: objawy somatyczne, na przykład, czy ostatnio miewałeś(aś) bóle głowy?; niepokój i bezsenność, na przykład, czy ostatnio zmartwienia nie 
Tabela 2. Podstawowe wyniki uzyskane na podstawie wykorzystanych kwestionariuszy

\begin{tabular}{|c|c|c|c|c|c|}
\hline \multirow[t]{2}{*}{ Kwestionariusz } & & \multicolumn{4}{|c|}{$N=86$} \\
\hline & & Min. & Maks. & M & SD \\
\hline \multirow{5}{*}{$\begin{array}{l}\text { SWS } \\
\text { (rodzina } \\
\text { i przyjaciele) }\end{array}$} & Informacyjne & 6 & 22 & 12,50 & 3,62 \\
\hline & Instrumentalne & 6 & 24 & 12,55 & 4,31 \\
\hline & Wartościujące & 6 & 28 & 12,41 & 4,46 \\
\hline & Emocjonalne & 6 & 21 & 10,62 & 4,29 \\
\hline & Wynik ogólny & 24 & 88 & 48,07 & 14,17 \\
\hline \multirow{5}{*}{$\begin{array}{l}\text { SWS } \\
\text { (profesjonaliści) }\end{array}$} & Informacyjne & 6 & 23 & 12,34 & 3,24 \\
\hline & Instrumentalne & 6 & 26 & 16,86 & 3,45 \\
\hline & Wartościujące & 6 & 27 & 15,23 & 3,67 \\
\hline & Emocjonalne & 6 & 21 & 13,78 & 3,66 \\
\hline & Wynik ogólny & 29 & 89 & 58,21 & 10,97 \\
\hline \multirow[t]{5}{*}{ GHQ-28 } & Symptomy somatyczne & 8 & 28 & 16,10 & 4,72 \\
\hline & Niepokój i bezsenność & 9 & 28 & 17,73 & 4,91 \\
\hline & Zaburzenia funkcjonowania & 9 & 28 & 16,10 & 3,82 \\
\hline & Symptomy depresji & 7 & 23 & 9,56 & 3,47 \\
\hline & Wynik ogólny & 36 & 93 & 59,50 & 13,71 \\
\hline
\end{tabular}

pozwalały Ci spać?; zaburzenia funkcjonowania, na przykład, czy ostatnio byłeś(aś) zadowolony(a) ze sposobu wykonywania swoich zadań?; i objawy depresji, na przykład, czy ostatnio myślałeś(aś) o możliwości odebrania sobie życia? Istnieje kilka sposobów punktacji odpowiedzi, jednak najczęściej wybierana jest metoda Likerta, którą zastosowano w niniejszym badaniu: 1-2-3-4 [23]. Współczynnik rzetelności $\alpha$ Cronbacha dla poszczególnych skal wynosi 0,84-0,89.

\section{Wyniki}

Weryfikacja wyników SWS w odniesieniu do rodziny i przyjaciół, SWS w kontekście profesjonalistów (lekarzy, pielęgniarek, psychologów) i GHQ-28 pozwoliła na identyfikację zależności między tymi wymiarami. Wyniki badań, które stanowią psychologiczną charakterystykę badanej grupy przedstawiono w tabeli 2 .

W kontekście wsparcia od rodziny i przyjaciół istotna jest zależność pomiędzy objawami depresji a wsparciem wartościującym i emocjonalnym. Większy brak w wymienionych wymiarach wsparcia współwystępuje ze wzmożonymi objawami depresji, natomiast mniejszy deficyt wsparcia instrumentalnego jest wiązany z częstszym występowaniem zaburzeń funkcjonowania (tab. 3).

Wynik ogólny GHQ-28 pozytywnie koreluje z wynikiem ogólnym SWS w odniesieniu do lekarzy, pielęgniarek, psychologów. Zatem, im większy deficyt wsparcia (zwłaszcza informacyjnego i wartościują- cego) od profesjonalistów, tym więcej problemów zdrowotnych w badanej grupie rodziców, przejawiających się najczęściej objawami depresji. Większy deficyt wsparcia informacyjnego od profesjonalistów towarzyszy większej liczbie objawów somatycznych, niepokoju i bezsenności oraz depresji. Niskie zaspokojenie potrzeby wsparcia wartościującego koreluje z występowaniem problemów związanych z niepokojem i bezsennością oraz z objawami depresji (tab. 4).

Analiza skupień przeprowadzona metodą k-średnich pozwoliła na wyodrębnienie 3 grup rodziców charakteryzujących się różnym nasileniem problemów zdrowotnych (wysokim, niskim, umiarkowanym) (tab. 5, ryc. 1). Do analizy wykresu nasilenia objawów w poszczególnych wymiarach zdrowia przyjęto następujące interpretacje wyników:

- wysokie nasilenie objawów - średnia powyżej 20,

- umiarkowane nasilenie - 15-20,

- niskie nasilenie - 10-15,

- bardzo niskie nasilenie objawów - poniżej 10.

Grupa 1 ( $n=13$ ) charakteryzuje się wysokimi wynikami w wymiarach: objawy somatyczne, niepokój i bezsenność, a także zaburzenia funkcjonowania, a niskimi w wymiarze objawów depresji. Grupa $2(n=35)$ to rodzice, których cechuje niski poziom nasilenia objawów somatycznych, niepokoju i bezsenności, zaburzeń funkcjonowania i bardzo niski poziom objawów depresji. Grupa $3(n=38)$ to osoby, które przejawiają umiarkowane problemy stanu zdrowia, umiarkowane nasilenie objawów somatycznych, 
Tabela 3. Współczynniki korelacji r-Pearsona między wymiarami Skali Wsparcia Społecznego w odniesieniu do rodziny i przyjaciół i Kwestionariusza Ogólnego Stanu Zdrowia GHQ-28

\begin{tabular}{lcccccc}
$\begin{array}{l}\text { Wsparcie spoleczne } \\
\text { w odniesieniu } \\
\text { do rodziny i przyjaciół }\end{array}$ & Korelacje & $\begin{array}{c}\text { Symptomy } \\
\text { somatyczne }\end{array}$ & $\begin{array}{c}\text { Niepokój } \\
\text { i bezsenność }\end{array}$ & $\begin{array}{c}\text { Zaburzenia } \\
\text { funkcjonowania }\end{array}$ & Depresja & $\begin{array}{c}\text { Wynik } \\
\text { ogólny }\end{array}$ \\
\hline Informacyjne & $\mathrm{r}$ &,- 012 &,- 086 &,- 111 &, 121 &,- 035 \\
\cline { 2 - 8 } & $\mathrm{p}$ &, 456 &, 215 &, 154 &, 134 &, 373 \\
\hline Instrumentalne & $\mathrm{r}$ &,- 097 &,- 072 &,$- 220^{*}$ &, 018 &,- 116 \\
\hline & $\mathrm{p}$ &, 188 &, 254 &, 021 &, 435 &, 144 \\
\hline Wartościujące & $\mathrm{r}$ &,- 083 &, 001 &, 060 &, $222^{*}$ &, 045 \\
\hline & $\mathrm{p}$ &, 224 &, 497 &, 293 &, 020 &, 342 \\
\hline Emocjonalne & $\mathrm{r}$ &,- 075 &,- 060 &,- 102 &, $200 *$ &,- 025 \\
\hline Wynik ogólny & $\mathrm{p}$ &, 246 &, 293 &, 174 &, 032 &, 409 \\
\hline & $\mathrm{r}$ &,- 081 &,- 062 &,- 108 &, 167 &,- 038 \\
\hline
\end{tabular}

${ }^{* *} p<0,01,{ }^{*} p<0,05$

Tabela 4. Współczynniki korelacji r-Pearsona między wymiarami Skali Wsparcia Społecznego w odniesieniu do profesjonalistów (lekarzy, pielęgniarek, psychologów) i Kwestionariusza Ogólnego Stanu Zdrowia GHQ-28

\begin{tabular}{|c|c|c|c|c|c|c|}
\hline \multirow{2}{*}{$\begin{array}{l}\text { Wsparcie społeczne } \\
\text { w odniesieniu } \\
\text { do profesjonalistów }\end{array}$} & \multirow[b]{2}{*}{ Korelacje } & \multicolumn{5}{|c|}{ Stan zdrowia } \\
\hline & & $\begin{array}{l}\text { Symptomy } \\
\text { somatyczne }\end{array}$ & $\begin{array}{c}\text { Niepokój } \\
\text { i bezsenność }\end{array}$ & $\begin{array}{c}\text { Zaburzenia } \\
\text { funkcjonowania }\end{array}$ & Depresja & $\begin{array}{l}\text { Wynik } \\
\text { ogólny }\end{array}$ \\
\hline \multirow{2}{*}{ Informacyjne } & $r$ &, $211 *$ &, $268 * *$ & ,070 & ,240* & ,249* \\
\hline & $p$ & ,026 & ,006 & 260 & ,013 & 010 \\
\hline \multirow[t]{2}{*}{ Instrumentalne } & $r$ &, 037 &,- 102 &,- 163 & ,119 &,- 039 \\
\hline & $p$ & 367 & 176 & ,067 & 138 & ,361 \\
\hline \multirow[t]{2}{*}{ Wartościujące } & $r$ & 160 &, $221 *$ & 157 &, 432 ** &, $287 * *$ \\
\hline & $p$ & ,070 & ,020 & ,074 & ,000 & ,004 \\
\hline \multirow[t]{2}{*}{ Emocjonalne } & $r$ & ,070 & 113 & ,023 & 177 &, 116 \\
\hline & $p$ & ,261 & 150 & ,418 &, 052 & ,144 \\
\hline \multirow[t]{2}{*}{ Wynik ogólny } & $r$ & , 151 & 159 & ,030 &, $311 * *$ & ,196* \\
\hline & $p$ & ,083 & ,072 & ,393 & ,002 & ,035 \\
\hline
\end{tabular}

${ }^{* *} p<0,01,{ }^{*} p<0,05$

zaburzeń funkcjonowania, wysokie w zakresie niepokoju i bezsenności oraz niskie nasilenie objawów depresji. Porównania poszczególnych grup dokonano za pomocą analizy wyników średnich i odchyleń standardowych (tab. 6), uzyskanych w poszczególnych skupieniach i przy zastosowaniu nieparametrycznego testu U Manna-Whitneya (tab. 7).

W grupie 1 i 2 (rodzice $z$ wysokim i niskim nasileniem problemów zdrowotnych) istotne różnice stwierdzono w każdym z wymiarów GHQ-28, podobnie jak pomiędzy grupą 2 i 3 (niskie i umiarkowane nasilenie problemów zdrowotnych). Natomiast przy porównaniu grup rodziców 1 i 3 (wysokie i umiarkowane nasilenie problemów zdrowotnych), różnice występują jedynie w trzech wymiarach: objawy somatyczne, niepokój i bezsenność oraz zaburzenia funkcjonowania.

Wyodrębnione grupy różnią się między sobą doświadczeniem wsparcia wartościującego od profesjonalistów (lekarzy, pielęgniarek, psychologów), co wykazano w analizie z zastosowaniem testu Kruskala-Wallisa. Szczegółowe statystyki przedstawiono 
Tabela 5. Liczba osób badanych w skupieniach

\begin{tabular}{lcc}
\hline \multicolumn{3}{l}{ Liczba osób w poszczególnych skupieniach $(n=86)$} \\
Skupienie & $n$ & $\%$ \\
\hline $\begin{array}{l}\text { Grupa } 1 \text { - rodzice z wysokim nasile- } \\
\text { niem trudności w zakresie zdrowia }\end{array}$ & 13 & 15,1 \\
\hline $\begin{array}{l}\text { Grupa } 2 \text { - rodzice z niskim nasileniem } \\
\text { trudności w zakresie zdrowia }\end{array}$ & 35 & 40,7 \\
\hline $\begin{array}{l}\text { Grupa } 3 \text { - rodzice z umiarkowanym } \\
\text { nasileniem trudności w zakresie zdrowia }\end{array}$ & 38 & 44,2 \\
\hline
\end{tabular}

w tabelach 8 i 9 . Wyniki wymagały dokonania porównań wielorakich, na podstawie których ustalono, że wartościujące wsparcie od profesjonalistów różnicuje grupę 2 i 3 - rodzice o umiarkowanym nasileniu problemów zdrowotnych posiadają większą potrzebę tego rodzaju wsparcia, w porównaniu z rodzicami o niskim nasileniu tych problemów. Istotne różnice pomiędzy grupami w zakresie wsparcia od profesjonalistów przedstawiono w tabeli 10 .

\section{Dyskusja}

Wyniki przeprowadzonego badania potwierdzają rezultaty uzyskane $\mathrm{w}$ badaniach innych autorów. Związek między doświadczanym wsparciem a stanem zdrowia rodziców zmagających się z chorobą dziecka widoczny jest zwłaszcza w odniesieniu do grupy profesjonalistów. Osoby, które wsparcie od lekarzy, pielęgniarek i psychologów oceniają, jako zadowalające, charakteryzuje lepsze samopoczucie.

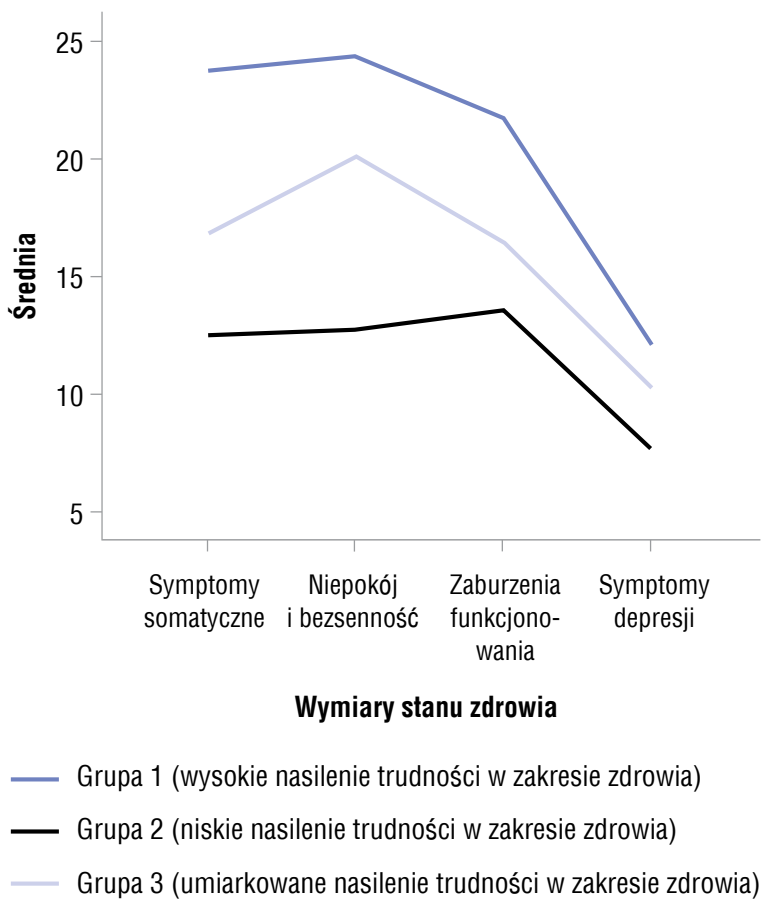

Rycina 1. Skupienia ze względu na wymiary stanu zdrowia

Badania rodziców dzieci hospitalizowanych wykazały, że wsparcie informacyjne, emocjonalne, wartościujące i instrumentalne pielęgniarek i lekarzy jest porównywalne. Badane osoby wskazują także na fakt, że wsparcie, które otrzymują, jest zdecydowanie niższe od oczekiwanego, zwłaszcza w obszarze wsparcia instrumentalnego [11]. Ponadto, jak wynika z innych badań, osoby, których różne oczekiwania względem

Tabela 6. Wyniki średnie i odchylenia standardowe w grupach dla poszczególnych wymiarów zdrowia

\begin{tabular}{lccccccc} 
Wymiary stanu zdrowia & \multicolumn{2}{c}{ Grupa $1(n=13)$} & \multicolumn{2}{c}{ Grupa $2(n=35)$} & \multicolumn{2}{c}{ Grupa $3(n=38)$} \\
& M & SD & M & SD & M & SD \\
Symptomy somatyczne & 23,77 & 3,37 & 12,49 & 2,20 & 16,82 & 3,08 \\
\hline Niepokój i bezsenność & 24,38 & 2,75 & 12,74 & 1,88 & 20,05 & 2,27 \\
\hline Zaburzenia funkcjonowania & 21,77 & 4,23 & 13,60 & 1,44 & 16,47 & 2,90 \\
\hline Symptomy depresji & 12,15 & 4,14 & 7,71 & 1,32 & 10,37 & 3,77 \\
\hline
\end{tabular}

Tabela 7. Istotność różnic pomiędzy grupami dla poszczególnych wymiarów zdrowia

\begin{tabular}{|c|c|c|c|c|c|c|}
\hline \multirow[t]{2}{*}{ Wymiary stanu zdrowia } & \multicolumn{2}{|c|}{ Porównanie grup 1 i 2} & \multicolumn{2}{|c|}{ Porównanie grup 1 i 3} & \multicolumn{2}{|c|}{ Porównanie grup 2 i 3} \\
\hline & $\begin{array}{c}\text { Test U } \\
\text { Manna-Whitneya }\end{array}$ & $\mathbf{p}$ & $\begin{array}{c}\text { Test U } \\
\text { Manna-Whitneya }\end{array}$ & $\mathbf{p}$ & $\begin{array}{c}\text { Test U } \\
\text { Manna-Whitneya }\end{array}$ & $\mathbf{p}$ \\
\hline Symptomy somatyczne & $-5,288^{*}$ & ,000 & $-4,547^{*}$ &, 000 & $-5,803^{*}$ &, 000 \\
\hline Niepokój i bezsenność & $-5,331 *$ &, 000 & $-4,162 *$ &, 000 & $-7,307^{*}$ &, 000 \\
\hline Zaburzenia funkcjonowania & $-5,119 *$ &, 000 & $-3,758 *$ &, 000 & $-4,927^{*}$ &, 000 \\
\hline Symptomy depresji & $-4,086^{*}$ &, 000 & $-1,471$ & 141 & $-4,400 *$ &, 000 \\
\hline
\end{tabular}


Tabela 8. Wyniki średnie i odchylenia standardowe w grupach dla poszczególnych wymiarów wsparcia społecznego

\begin{tabular}{|c|c|c|c|c|c|c|}
\hline & \multicolumn{2}{|c|}{ Grupa 1 (n = 13) } & \multicolumn{2}{|c|}{ Grupa 2 (n = 35) } & \multicolumn{2}{|c|}{ Grupa 3 (n = 38) } \\
\hline & M & SD & M & SD & M & SD \\
\hline \multicolumn{7}{|c|}{ Wsparcie społeczne od rodziny i przyjaciół } \\
\hline Informacyjne & 11,69 & 3,57 & 12,80 & 3,75 & 12,50 & 3,58 \\
\hline Instrumentalne & 11,08 & 3,38 & 12,74 & 4,55 & 12,87 & 4,36 \\
\hline Wartościujące & 11,62 & 4,33 & 12,29 & 4,99 & 12,79 & 4,05 \\
\hline Emocjonalne & 9,15 & 3,31 & 10,83 & 4,67 & 10,92 & 4,23 \\
\hline Wynik ogólny & 43,54 & 11,47 & 48,66 & 15,44 & 49,08 & 13,82 \\
\hline \multicolumn{7}{|c|}{ Wsparcie społeczne od profesjonalistów } \\
\hline Informacyjne & 12,77 & 5,15 & 11,34 & 3,00 & 13,11 & 2,38 \\
\hline Instrumentalne & 16,00 & 5,49 & 16,80 & 2,76 & 17,21 & 3,18 \\
\hline Wartościujące & 14,62 & 4,66 & 13,97 & 3,05 & 16,61 & 3,43 \\
\hline Emocjonalne & 13,23 & 4,66 & 13,34 & 3,54 & 14,37 & 3,40 \\
\hline Wynik ogólny & 56,62 & 17,12 & 55,46 & 9,36 & 61,29 & 9,13 \\
\hline
\end{tabular}

Tabela 9. Różnice między grupami w zakresie wsparcia społecznego

\begin{tabular}{|c|c|c|}
\hline & $x^{2}$ & $\mathbf{p}$ \\
\hline \multicolumn{3}{|c|}{ Wsparcie społeczne od rodziny i przyjaciół } \\
\hline Informacyjne & 746 & ,689 \\
\hline Instrumentalne & 1,415 & ,493 \\
\hline Wartościujące & 1,289 &, 525 \\
\hline Emocjonalne & 1,937 & ,380 \\
\hline Wynik ogólny & 1,158 & ,560 \\
\hline \multicolumn{3}{|c|}{ Wsparcie społeczne od profesjonalistów } \\
\hline Informacyjne & 5,014 & 082 \\
\hline Instrumentalne &, 589 & ,745 \\
\hline Wartościujące & $8,200 *$ & 017 \\
\hline Emocjonalne & 1,331 & ,514 \\
\hline Wynik ogólny & 5,482 & ,065 \\
\hline
\end{tabular}

innych nie są zaspokojone, mogą odczuwać wiele trudnych emocji. Można stąd wnosić, że niezaspokojone potrzeby (m.in. wsparcia) mają odzwierciedlenie w wyrażaniu niezadowolenia z opieki [24].

Wśród zmiennych warunkujących satysfakcję pacjentów z jakości opieki medycznej wymienia się między innymi potrzebę informacji oraz zainteresowania i wsparcia społecznego $[25,26]$. Analizy przeprowadzone na podstawie badań własnych potwierdzają, że większy deficyt wsparcia informacyjnego od profesjonalistów współwystępuje $z$ dolegliwościami somatycznymi, poczuciem niepokoju i bezsenności oraz z objawami depresyjnymi. Problem ten wydaje się być jednak bardziej złożony, ponieważ jak wykazały badania Maree i wsp. [27], poszczególni rodzice mają różne opinie na temat tego, w jaki sposób, kiedy i jakie dokładnie informacje powinny być im przekazywane. Autorzy podkreślają znaczenie zindywidualizowanego podejścia do informowania o stanie zdrowia dziecka, mającego wpływ na jakość życia rodziców. W badaniach własnych ogólny poziom wsparcia od profesjonalistów ma związek ze stanem zdrowia w badanej grupie - im większy jego deficyt, tym gorsze samopoczucie wśród rodziców.

Warto wspomnieć, że wsparcie wartościujące oceniane w odniesieniu do grupy profesjonalistów różnicuje grupę z niskim i umiarkowanym nasileniem trudności zdrowotnych. Rodziców z grupy 2 (niskie nasilenie trudności w stanie zdrowia) cechuje mniejsze zapotrzebowanie na wsparcie wartościujące, w porównaniu z osobami z grupy 3 (umiarkowane nasilenie). Zatem, mniejsza potrzeba zapewniania o tym, że jest się ważną osobą, z której zdaniem należy się liczyć współwystępuje z lepszym samopoczuciem. W kontekście tej obserwacji można sformułować pytanie, dlaczego różnic tych nie stwierdzono w zestawieniu z grupą o wysokich trudnościach zdrowotnych? Być może grupa rodziców, którzy przejawiają największe problemy zdrowotne była mniej liczna lub ich własne trudności ze zdrowiem sprawiają, że kwestia wsparcia staje się dla nich nieistotna. Niemniej hipotezy te należałoby sprawdzić w przyszłych badaniach.

Najważniejszą grupą wsparcia w sytuacji choroby dziecka jest rodzina [26]. Badania własne wykazały, że rodzice, którzy mają przekonanie, że dla bliskich są osobami ważnymi, przejawiają mniej objawów 
Tabela 10. Istotność różnic pomiędzy grupami dla wsparcia społecznego od profesjonalistów

\begin{tabular}{|c|c|c|c|c|c|c|}
\hline \multirow{2}{*}{$\begin{array}{l}\text { Wsparcie społeczne od } \\
\text { profesjonalistów }\end{array}$} & \multicolumn{2}{|c|}{ Porównanie grup 1 i 2} & \multicolumn{2}{|c|}{ Porównanie grup 1 i 3} & \multicolumn{2}{|c|}{ Porównanie grup 2 i 3} \\
\hline & $\begin{array}{c}\text { Test U } \\
\text { Manna-Whitneya }\end{array}$ & $\mathbf{p}$ & $\begin{array}{c}\text { Test U } \\
\text { Manna-Whitneya }\end{array}$ & $\mathbf{p}$ & $\begin{array}{c}\text { Test U } \\
\text { Manna-Whitneya }\end{array}$ & p \\
\hline Informacyjne &,- 896 & ,370 &,- 196 & ,845 & $-2,334^{*}$ & ,020 \\
\hline Instrumentalne &,- 573 &, 567 &,- 708 & ,479 &,- 361 & ,718 \\
\hline Wartościujące &,- 665 &, 506 &,- 946 &, 344 & $-2,972^{*}$ & ,003 \\
\hline Emocjonalne &,- 093 & 926 &,- 728 & ,467 & $-1,093$ & 274 \\
\hline Wynik ogólny &,- 209 & 834 &,- 919 & ,358 & $-2,438^{*}$ & 015 \\
\hline
\end{tabular}

depresyjnych. Interesujący poznawczo jest natomiast wynik badania, zgodnie z którym większe zaspokojenie rodziców w zakresie wsparcia instrumentalnego otrzymywanego od rodziny i przyjaciół, współwystępuje z częściej doświadczanymi trudnościami w funkcjonowaniu. Być może ciągłe oferowanie przez najbliższych pomocy sprawia, że badani czują się tak, jakby w ocenie innych nie potrafili normalnie funkcjonować. Należałoby jednak poszerzyć badania, aby taki wniosek jednoznacznie sformułować.

Przeprowadzone do tej pory badania potwierdzają konieczność opracowania i stosowania programów wsparcia społecznego dla rodziców dzieci chorych na nowotwory $[9,28,29]$. Przedstawione wyniki i sformułowane na ich podstawie wnioski mogą mieć zastosowanie w praktyce klinicznej. Być może niektóre problemy ze zdrowiem rodziców dzieci z chorobami nowotworowymi mają podłoże w niezadowoleniu z doświadczanego wsparcia społecznego i jego nieadekwatności. Odpowiednia sieć wsparcia i odpowiedź na oczekiwania rodziców mogą wspomóc ich radzenie sobie z sytuacją choroby dziecka. Należy jednak pamiętać, że przeprowadzone badania cechują pewne ograniczenia. Zmienne, które poddano sprawdzeniu nie wyjaśniają w pełni problemów rodziców dzieci z chorobami nowotworowymi. Każdy człowiek jest inny i tylko indywidualne, a zarazem holistyczne podejście do osoby, może być przydatne w zrozumieniu jej i niesieniu pomocy w obszarach życia, do których drugi człowiek zostanie zaproszony.

\section{Wnioski}

Brak wsparcia informacyjnego uzyskiwanego od profesjonalistów współwystępuje z dolegliwościami somatycznymi, poczuciem niepokoju i bezsenności oraz z objawami depresji w grupie rodziców dzieci chorych na nowotwory.

Mniejsza potrzeba wsparcia wartościującego od profesjonalistów współwystępuje z lepszym samopoczuciem rodziców.
Rodzice, którzy są zadowoleni ze wsparcia, jakie otrzymują od bliskich, doświadczają mniej objawów depresji.

\section{Konflikt interesów}

Autorzy deklarują brak konfliktu interesów.

\section{Finansowanie}

Badanie nie było finansowane.

\section{References}

1. Zuberek-Moskal U. Rodzina w sytuacji wyznaczonej chorobą nowotworową dziecka. In: Kubacka-Jasiecka D, Łosiak W. ed. Zmagając Się z Chorobą Nowotworową. Psychologia Wobec Pacjentów Onkologicznych. Wydawnictwo Uniwersytetu Jagiellońskiego, Kraków 1999: 261-263.

2. Muscara F, McCarthy MC, Woolf C, et al. Early psychological reactions in parents of children with a life threatening illness within a pediatric hospital setting. Eur Psychiatry. 2015; 30(5): 555-561, doi: 10.1016/j.eurpsy.2014.12.008, indexed in Pubmed: 25618445.

3. Deręgowska J. Dziecko z Chorobą Nowotworową w Rodzinie. Diagnoza-Wsparcie. Wydawnictwo Naukowe Wyższej Szkoły Nauk Humanistycznych i Dziennikarstwa, Poznań 2010.

4. Sęk H, Cieślak R. Wsparcie społeczne - sposoby definiowania, rodzaje i źródła wsparcia, wybrane koncepcje teoretyczne. In: Sęk H, Cieślak R. ed. Wsparcie społeczne, stres i zdrowie. Wydawnictwo Naukowe PWN, Poznań 2006: 11-28.

5. Kacperczyk A. Wsparcie Społeczne w Instytucjach Opieki Paliatywnej i Hospicyjnej. Wydawnictwo Uniwersytetu Łódzkiego, Łódź 2006.

6. Pelentsov $\sqcup$, Laws TA, Esterman AJ. The supportive care needs of parents caring for a child with a rare disease: A scoping review. Disabil Health J. 2015; 8(4): 475-491, doi: 10.1016/j.dhjo.2015.03.009, indexed in Pubmed: 25959710.

7. Ziółkowska B. Dziecko chore w domu, w szkole i u lekarza. Jak wspomagać rozwój dzieci przewlekle chorych. Gdańskie Wydawnictwo Psychologiczne, Gdańsk 2010.

8. Wyszomirska J, Gajda M, Janas J, et al. Ocena wpływu wsparcia społecznego na psychiczne przystosowanie do choroby nowotworowej pacjentów w trakcie leczenia paliatywnego lub radykalnego. Psychoonkologia. 2014; 3: 89-96.

9. Burkiewicz A, Samardakiewicz M, Karczmarczyk T. The level of depression and perceived social support in parents of children treated for cancer. Psychoonkologia. 2017; 21(1): 17-21, doi: 10.5114/pson.2017.70123. 
10. Kędzierska B, Rol P, Wiktorowicz J. Indicators of posttraumatic stress in parents of children finishing cancer treatment - the role of medical care, social support and resiliency. Psychoonkologia. 2016; 20(1): 9-16, doi: 10.5114/pson.2016.60922.

11. Mazur A, Aftyka A, Sipta A, et al. Expected and received support from the medical personnel in the perception of parents of children treated in hospital. Psychoonkologia. 2016; 20(4): 183-190, doi: 10.5114/pson.2016.66290.

12. Ogińska-Bulik N. Personal resources and posttraumatic growth of parents struggling with cancer disease of their child. Psychoonkologia. 2017; 21(1): 9-16, doi: 10.5114/pson.2017.70122.

13. Ogińska-Bulik N, Socha I. Emotional processing and negative and positive effects of trauma among parents struggling with cancer of their child. Psychoonkologia. 2017; 21(1): 1-8, doi: 10.5114/pson.2017.70121.

14. Kazak AE, Boeving CA, Alderfer MA, et al. Posttraumatic stress symptoms during treatment in parents of children with cancer. J Clin Oncol. 2005; 23(30): 7405-7410, doi: 10.1200/JCO.2005.09.110, indexed in Pubmed: 16157936.

15. Hamner T, Latzman RD, Latzman NE, et al. Quality of life among pediatric patients with cancer: Contributions of time since diagnosis and parental chronic stress. Pediatr Blood Cancer. 2015; 62(7): 1232-1236, doi: 10.1002/pbc.25468, indexed in Pubmed: 25755193.

16. Pöder U, Ljungman G, von Essen L. Posttraumatic stress disorder among parents of children on cancer treatment: a longitudinal study. Psychooncology. 2008; 17(5): 430-437, doi: 10.1002/pon.1263, indexed in Pubmed: 17847123.

17. Sloper P. Predictors of distress in parents of children with cancer: a prospective study. J Pediatr Psychol. 2000; 25(2): 79-91, doi: 10.1093/jpepsy/25.2.79, indexed in Pubmed: 10820946.

18. Yang $X$, Wang $L$, He J, et al. Factors related to depressive symptoms among Chinese caregivers of cancer patients. Psycho-Oncology. 2011; 21(10): 1063-1070, doi: 10.1002/pon.1999.

19. Tardy C. Social suport measurment. American Journal of Community Psychology. 1985; 13(2): 187-202.
20. Makowska Z, Merecz D. Polska adaptacja kwestionariuszy ogólnego stanu zdrowia Davida Goldberga GHQ12 i GHQ-28. In: Dudek B. ed. Ocena zdrowia psychicznego na podstawie badań kwestionariuszami Davida Goldberga. Instytut Medycyny Pracy im. prof. J. Nofera, Łódź 2001: 191-264.

21. Kmiecik-Baran K. Skala Wsparcia Społecznego. Teoria i wartości psychometryczne. Przegląd Psychologiczny. 1995; 38(1/2): 201-214.

22. Goldberg D, Williams P. Podręcznik dla użytkowników Kwestionariusza Ogólnego Stanu Zdrowia (translation: D. Merecz). In: Dudek B. ed. Ocena zdrowia psychicznego na podstawie badań kwestionariuszami Davida Goldberga. Instytut Medycyny Pracy im. prof. J. Nofera, Łódź 2001: 13-189.

23. Frydecka D, Małyszczak K, Chachaj A, et al. Struktura czynnikowa Kwestionariusza Ogólnego Zdrowia (GHQ-30). Psychiatria Polska 2010; XLIV. ; 3: 341-359.

24. Moczydłowska A, Krajewska-Kułak E, Kózka M, et al. Oczekiwania chorych wobec personelu lekarskiego. Hygeia Public Health. 2014; 49(1): 142-151.

25. Mykowska A. Satysfakcja pacjenta a jakość obsługi medycznej. Zdrowie i Zarządzanie. 2002; 6: 69-73.

26. Grzegorczyk A, Szewczyk L. Ocena wsparcia społecznego rodziców dzieci z chorobami neurologicznymi. Aspekty zdrowia i Chor. 2016; 1(4): 55-65.

27. Maree JE, Parker S, Kaplan L, et al. The Information Needs of South African Parents of Children With Cancer. J Pediatr Oncol Nurs. 2016; 33(1): 9-17, doi: 10.1177/1043454214563757, indexed in Pubmed: 25643969.

28. Kamihara J, Nyborn JA, Olcese ME, et al. Parental hope for children with advanced cancer. Pediatrics. 2015; 135(5): 868-874, doi: 10.1542/peds.2014-2855, indexed in Pubmed: 25847801.

29. Masa'deh R, Jarrah S. Post Traumatic Stress Disorder in Parents of Children With Cancer in Jordan. Arch Psychiatr Nurs. 2017; 31(1): 8-12, doi: 10.1016/j.apnu.2016.07.012, indexed in Pubmed: 28104064. 